\title{
A Marxist Theory of Ideology
}

This work explores the question of defining ideology from a Marxist perspective. Advancing beyond the schemas of discussion presented in current Marxist literature, the author offers an account of how the concept of ideology should be defined and what role it plays within historical materialism. Through a close reading of Karl Marx's relevant writings, this volume demonstrates that while there is no coherent, single account of ideology in Marx's work, his materialist framework can be reconstructed in a defensible and 'non-deterministic' way. The definition of ideology presented is then articulated through a close reading of Antonio Gramsci's Prison Notebooks. Efforts are also made to demonstrate that Gramsci's interpretation of historical materialism is indeed consistent and compatible with Marx's. A systematic articulation of a theory of ideology that combines the works of Marx and Gramsci, as well as adding elements of Pierre Bourdieu's social theory and William James's psychology, this volume will appeal to scholars of social and political theory with interests in political economy and Marxist thought.

Andrea Sau is Lecturer in Politics and International Relations at St Mary's University Twickenham. He has also taught at the University of Hertfordshire and King's College London, where he completed his PhD. 


\section{Routledge Studies in Social and Political Thought}

\section{The Social Life of Nothing}

Silence, Invisibility and Emptiness in Tales of Lost Experience

Susie Scott

146 A Politics of Disgust

Selfhood, World-Making and Ethics

Eleonora Joensuu

147 The Lived Experiences of Muslims in Europe

Recognition, Power and Intersubjective Dilemmas

Des Delaney

148 Ethical Politics and Modern Society

T. H. Green's Practical Philosophy and Modern China

James Jia-Hau Liu

149 Consciousness and the Neoliberal Subject

A Theory of Ideology via Marcuse, Jameson and Žižek

Jon Bailes

150 Hegel and Contemporary Practical Philosophy

Beyond Kantian-Constructivism

James Gledhill and Sebastian Stein

151 A Marxist Theory of Ideology

Praxis, Thought, and the Social World

Andrea Sau

152 Stupidity in Politics

Its Unavoidability and Potential

Nobutaka Otobe

For a full list of titles in this series, please visit www.routledge.com/series/RSSPT 


\section{A Marxist Theory of Ideology Praxis, Thought, and the Social World}

\section{Andrea Sau}


First published 2020

by Routledge

2 Park Square, Milton Park, Abingdon, Oxon OX14 4RN

and by Routledge

52 Vanderbilt Avenue, New York, NY 10017

Routledge is an imprint of the Taylor \& Francis Group, an informa business

(C) 2020 Andrea Sau

The right of Andrea Sau to be identified as author of this work has been asserted by him in accordance with sections 77 and 78 of the Copyright, Designs and Patents Act 1988.

All rights reserved. No part of this book may be reprinted or reproduced or utilised in any form or by any electronic, mechanical, or other means, now known or hereafter invented, including photocopying and recording, or in any information storage or retrieval system, without permission in writing from the publishers.

Trademark notice: Product or corporate names may be trademarks or registered trademarks, and are used only for identification and explanation without intent to infringe.

British Library Cataloguing-in-Publication Data

A catalogue record for this book is available from the British Library

Library of Congress Cataloging-in-Publication Data

Names: Sau, Andrea, 1988- author.

Title: A Marxist theory of ideology : praxis, thought and the social world /

Andrea Sau.

Description: Abingdon, Oxon ; New York, NY : Routledge, 2020.|

Series: Routledge studies in social and political thought |

Includes bibliographical references and index.

Identifiers: LCCN 2020004596 (print) | LCCN 2020004597 (ebook) |

ISBN 9780367409630 (hardback) | ISBN 9780367810146 (ebook)

Subjects: LCSH: Marx, Karl, 1818-1883. | Ideology. | Communism. |

Socialism. | Philosophy, Marxist.

Classification: LCC HX39.5 .S2327 2020 (print) | LCC HX39.5 (ebook) |

DDC 320.5--dc23

LC record available at https://lccn.loc.gov/2020004596

LC ebook record available at https://lccn.loc.gov/2020004597

ISBN: 978-0-367-40963-0 (hbk)

ISBN: 978-0-367-81014-6 (ebk)

Typeset in Times New Roman

by Taylor \& Francis Books 
'Men make their own history, but they do not make it as they please; they do not make it under self-selected circumstances, but under circumstances existing already, given and transmitted from the past'.

Marx, K. (1979) p. 103. 


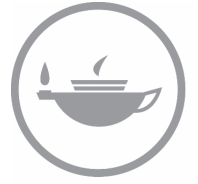
Taylor \& Francis Taylor \& Francis Group http://taylorandfrancis.com 


\section{Contents}

Acknowledgements viii

Introduction 1

1 Why another Marxist theory of ideology? 10

2 Historical materialism and ideology 63

3 Commodity fetishism 125

4 Gramsci's Marxism 157

5 Praxis, thought, and the social world 195

$\begin{array}{ll}\text { Conclusion } & 219\end{array}$

Bibliography $\quad 222$

$\begin{array}{ll}\text { Index } & 226\end{array}$ 


\section{Acknowledgements}

I would like to thank Alex Callinicos for his outstanding supervision. I greatly appreciated his comments, criticisms, and efforts to make me stick to the topic, but also his faith in my intuitions. I am also thankful to Jan Rehmann for his encouraging comments on this work's early drafts. A special mention goes to my dear friend David L. T. Sommer (UCL), who read countless passages from various drafts. Our discussions, and his ruthless criticisms of my ideas, were absolutely central to the development of the concepts presented in this book. At Routledge, I would like to thank Neil Jordan for all his help in getting my $\mathrm{PhD}$ in shape for publication and Alice Salt for her guidance and support. I am also thankful to Anna Dolan and Judit Varga for their excellent copy-editing work. Finally, I would like to thank Emily D. Greener and my family, especially my mum, for all her encouragement and support throughout the years.

Grazie mamma! 


\section{Introduction}

As the title states, this book presents a Marxist theory of ideology. While this work attempts to deal with complex issues relating to the literature on the topic (which might interest the erudite reader), I also do my best to explain the material discussed in some depth as well as providing definitions for most of the concepts presented. This is to make the book intelligible to those unfamiliar with the literature surrounding Marx and ideology. In other words, this work tries to cater for the needs of students approaching Marxist theory for the first time, as well as providing the level of depth necessary to satisfy more knowledgeable readers. This introduction will directly address both groups by answering what I assume to be their most pressing questions upon reading the title:

The student might wonder: What is Marxism? And what is ideology?

The academic might simply ask: Why do we need another one of 'those'?

Let us begin by trying to make this whole discussion intelligible to those unfamiliar with the topic. Although mostly known for his support of communism, Marx also presented $\boldsymbol{a}$ sketch (we must emphasise the cryptic nature of Marx's remarks on the matter) for a theory of history, that later came to be known as historical materialism. Marx's theory emphasises the role of the economy (understood in the usual sense of production, consumption and distribution of things) in determining societies' culture and politics, as well as their overall historic development. In other words, Marx offered what might be called an economic determinist account of development and change. This was expressed in terms of technological advancement (insofar as technology is a product of labour, which in turn effects how production is carried out) but also by reference to what Marx calls class struggle.

The idea of technological development determining society should not be understood as the transformation of individuals into puppets by technology. Rather, as the fact that new technologies lead to a development in both human needs (by shaping the way existing needs are satisfied and by producing further needs for the technological objects themselves) and capacities. This, in turn, leads to the transformation of culture in general, as the behaviour of individuals is altered by the new magical objects. This is what Marx meant when he said that: 


\section{Introduction}

The object is not an object in general, but a definite object which must be consumed in a definite way, a way mediated by production itself. The hunger gratified by cooked meat eaten with a knife and fork is a different hunger from that which bolts down raw meat with the aid of hand, nail and tooth. Production thus produces not only the object but also the manner of consumption, not only objectively but also subjectively. Production thus creates the consumer. Production not only supplies a material for the need, but it also supplies a need for the material. ${ }^{1}$

While the reader might be persuaded by the above argument and recognise the immense impact of technology on culture, class struggle might appear to be something irrelevant in a world where the internet and social media have created new avenues for the consumption and production of things. Why do we still need the old story of struggle between capitalists and workers? Although the existence of social media and streaming platforms might appear to contradict Marx's framework, a closer look reveals the ever-lasting importance of his concepts. Indeed, the way in which the internet has created new avenues of production and profit-making implicitly shows that Marx's combination of technological development and class struggle is still needed to approach social reality. Marx foresaw how technological development would lead, not only to the creation of new capacities and needs (e.g., we can now produce and distribute information from the comforts of our homes), but also to newer avenues of production and profitmaking. Since profit making, as we will explain later, ${ }^{2}$ always entails the exploitation of someone's labour, ${ }^{3}$ technological development and class struggle must always be kept in mind in their unity and mutual determination.

Under capitalism all production entails an uneven relationship between the resources (money) accumulated by the capitalists (those that own the means of production) and the ones appropriated by the workers (those who employ their labour in exchange for wages). Ultimately, even if we must acknowledge that our new world is far from the reality depicted by Marx, the inequalities of our society and the consequential problems those inequalities bring about are still rooted in the uneven relationship between the owners of the means of production (capitalists) and those who do not possess the means of production and so must sell their labour (workers). When we speak of class struggle, we must not think, necessarily, of strikes and union actions (overt cases of struggle). The concept must rather be postulated as a constant feature of the capitalist system insofar as the capital/labour relationship entails a conflict of interest. The capitalist has an interest in paying the workers as little as possible (the less the costs, the more the returns) while the workers benefit from higher wages. The incentives that lead our capitalists to initiate production, as well as the motivations that lead them to seek technological

1 Marx, K. (1987a) p. 29.

2 Exploitation in general will be explained on p. 98, exploitation under capitalism on pp. 134-140.

3 Unless we are talking of financial capital. 
development, have remained unaltered. We all know that everything is created for profit. No production would occur if this incentive did not exist. Furthermore, we must not forget that the factory production described by Marx still exists today. We can know this by simply checking the labels on our clothes. Our leisure and consumption still rely on the toil of those producing 'the materials' necessary for our cyber lives. Indeed, no 'digital production' can exist without the technology which allows this, while the technology relies on the material production of factory workers in developing countries, whose exploitation is not something anyone can doubt. By using classical Marxist concepts, the recent works of authors like Christian Fuchs have shown that the processes involved in digital labour still function according to the logics of capitalist accumulation and workers' exploitation. Furthermore, Fuchs emphasises the relationship between digital labour and the exploitation of 'regular/physical labour' in order to construct our computers, phones, etc., as well as the exploitations of the workers employed in the process:

Retailers of $\mathrm{ICTs}^{4}$ buy products from large ICT producers, who tend to outsource hardware manufacturing and buy the hardware components from other companies that buy metals from processing companies that buy raw materials from middlemen who buy them from primary extractors. This complex global value chain involves many nested social relations so that the underlying social relations are not visible at the upper level. Consumers know which label is on their mobile phone or laptop and from which retailer they bought the device, but the dead thing they possess does not talk; it is rather silent on the living labour relations that created it. ${ }^{5}$

It is interesting to see how the advent of the internet has brought about a renaissance in Marxist theory, with authors such as Fuchs, Rudi Schmiede, Jodi Dean, Lisa Nakamura and Nick Dyer-Witheford employing Marxist notions to study the internet. For all these reasons, I believe that Marx still has much to teach us.

Marx has also something to tell us about our political situation. Indeed, the current instability within Western capitalist 'democracies' can be explained by reference to Marx's analysis of capitalism:

1 Capital invests abroad to take advantage of the cheaper labour and looser regulations of developing countries. This translates in less investment, and thus rising unemployment at home.

2 Although technology creates new avenues of productions, it also destroys jobs by replacing workers with machines. ${ }^{6}$

4 Information and communications technology.

5 Fuchs, C. (2014) pp. 173-174.

6 Mainstream economists argue that the two tendencies are in equilibrium (x number of new jobs replacing $\mathrm{x}$ number of lost jobs), but we should have all reasons to doubt this. 


\section{Introduction}

The more knowledgeable reader might have a problem with the analysis above. Indeed, most Marxist theories, by emphasising the role of economic interests, tend reduce the role of politicians and the state to the sustainment and further development of capitalist logics. This was almost perceived as a fact in the (pre-2008 crisis) neoliberal era of privatisation, de-regulation, free trade, low spending and high levels of international competition. But now we witness the return of nationalism and protectionism, two trends that disrupt global production, and thus hinder the interests of the transnational capitalist class. How can a Marxist explain all this? I became interested in the concept of ideology to understand the complexities of the relationship between economic structures and politics. I then came to the conclusion that to overcome the extreme economic determinism (economic interests completely determine politics) of some readings of Marx, a conception of ideology emphasising the different ways in which the same economic situation (and the broader social world) could be interpreted by different groups was necessary. The knowledgeable reader might find this enterprise problematic. Indeed, Marxist and critical theories tend to conceive ideology as something to do with the reproduction of the socio-economic order. Within this tradition, ideology is generally conceived as a process of socialisation that 'makes' individuals, as a form of distortion (e.g., a biased narrative justifying the socio-economic order), or as a vehicle for the interests of dominant classes. While the first notion is linked to the reproduction of the system, the second one relates to its justification (that is also, in a broader sense, viewed as part of reproduction). Finally, conceptions of the third type tend to understand ideology as specific narratives that justify the economic interests of the ruling classes, while those interests are understood broadly, and thus often equated with the sustainment of the capitalist socio-economic order (from which capitalists benefit). Unfortunately, none of these can help explain development and change, as they do not acknowledge the existence of struggles between dominant classes/groups. They often assume a united ruling class imposing one narrative brainwashing individuals into accepting the socio-economic order. Although critical theories nowadays acknowledge the struggle between dominant and subordinate groups, the conflict between dominant groups themselves is hardly ever discussed. The latter, in my view, has a central role in determining the ways I which people interpret the world, as political leaders all offer different social commentaries that support their respective policies (and the medias' perspective is generally shaped by this competition, as different outlets support/condemn different parties). Political competition cannot be acknowledged by the existing critical approaches to ideology as they tend to view all bourgeois narratives as 'more or less the same'. I believe this is a serious mistake. The struggles between political groups and their ideas, have an important historical role. In my view, it is politics and ideology which make the social world so unpredictable. Ideology provides the vision for political action by interpreting and explaining the social world, and so one cannot predict what views will prevail, what plans will be actualised, and 
what changes will be brought to the cultural, economic, and political realms of society. Although I agree with the third notion of ideology conceived as a vehicle of class interests, we must acknowledge that, beside the general support for the capitalist order (which all bourgeois ideologies have in common), ideologies also express more specific material interests (e.g., party b wants development of industry $\mathrm{x}$ ) and other broader interests (e.g., cultural/religious matters) and values. Thus, the struggles between a decaying neoliberal ideology against right-wing populism should not be underestimated. We do not know where this conflict might lead.

At this point, the erudite reader might argue that what I propose here has already been done by postmodern thinkers, whose emphasis on subjectivity, interpretation and meaning is now a trademark of today's critical theory. I am trying to escape Marx's determinism by including meaning and subjectivity, and so the 'Marxism' proposed here, is more of a 'post-Marxism'. This would be an erroneous understanding of the present enterprise. First of all, although ideology brings interpretation and meaning to the methodological table, distinctions will be made between the economic structure and its internal (to borrow from Robert Brenner) "rules for reproduction" ${ }^{7}$ whose logics are constant and affirm themselves through the reproduction of the socio-economic order (even though what is produced, consumed and distributed varies, the social relations through which production, consumption and distribution operate are constant) and the more contingent aspects relating to ideologies and political action. The problem of interpretation is also conceived in a way that is much narrower than what is proposed by postmodern thinkers. Their method makes no distinctions (indeed they are against distinctions) between interpretations of capitalism and (let us say) films. Everything is mediated through interpretation and thus everything should be object to critical scrutiny. In this book, I will emphasise the overriding importance of the interpretations of the social world, rather than interpretations per-se. Indeed, while our interpretations of texts, songs, cats, dogs and what not, have little social consequences, interpretations and explanations of the social world (key features of ideology according to our interpretation) have tremendous political impact insofar as they inspire collective political action. The postmodern method presents a world that is too undifferentiated and indeterminate to even begin to narrow down the politically salient types of interpretation.

This work also addresses critical theory's passive conception of the individual. This is an issue for both Marxist (as we will see in our analysis of Louis Althusser and Georg Lukacs) and postmodern approaches. Indeed, even if the latter group emphasises indeterminacy, non-homogeneity and unpredictability, they still conceive some 'dominant discourse' which 'constitutes subjects' (that is, in postmodern lingo, the 'making of individuals'). Critical theory tends to see individuals as puppets. Thoughtless cogs in the machine. And while Marxists theorists see 'the escape' from this condition in holistic

7 Brenner, R. (2007) p. 59. 


\section{Introduction}

Marxist knowledge and revolution, postmodern thinkers see no way out. This dominant discourse produces the 'voluntary servitude' of the masses to the socio-economic order, while destroying any capacity for critical thinking (although, somehow, Marxist and postmodern thinkers are practically immune to this discourse as they can detect it and criticise it). To me, this way of conceiving the consent of the masses to the socio-economic world is both wrong and dehumanising. To use Baruch Spinoza's words:

If men's minds were as easily controlled as their tongues, every king would sit safely on his throne, and government by compulsion would cease; for every subject would shape his life according to the intentions of his rulers, and would esteem a thing true or false, good or evil, just or unjust, in obedience to their dictates. However, (...) no man's mind can possibly lie wholly at the disposition of another, for no one can willingly transfer his natural right of free reason and judgment, or be compelled so to do. ${ }^{8}$

Humans think for themselves. No dominant discourse is powerful enough to completely numb our brains. Indeed, in this work, the individual will be conceived in the Gramscian way, as a philosopher. Even if we admit the existence of conformism and crowd thinking, how can we know that group-thinking is truly accepted by the individual? How do we know that our individual is not simply pretending, just to fit in, while his mind sees the wrongs in his peers' ways of thinking? The whole idea of the 'constitution of the subject' is in my view very elitist. It entails that only academics are (as if blessed with some special skill) able to think critically. It must be rejected altogether as it serves no purpose. The problem of people's consent to unjust socio-economic orders should be posed from a practical perspective rather than in terms of thought. The fact that people consent to the socio-economic order does not mean that they support it on a conceptual level. I am here writing a work on Marx, yet I participate in capitalism's reproduction. This is unavoidable for me unless a communist society were to rise tomorrow. Therefore, the problem of consent will be viewed through the logics of Pierre Bourdieu's habitus/field dichotomy and will not entail 'voluntary servitude', but rather a perceived necessary servitude (one must join the socio-economic order to have a 'normal life'). In fact, instead of talking of constitution, this work will conceive individuals as being educated and habituated to accept and respond to the social structures they encounter in their lives. Whether they also accept those structures uncritically and without reservation, frustration and anger, we cannot know. They are simply forced to accept them because they exist, and they appear (practically speaking) to be necessary. I will argue that ideology can function as a justification for the socio-economic order (even though it can also take the form of criticism) which homogenises individuals in their conceptions of

8 Spinoza, B. (2007) p. 257. 
the social world. However, ultimately, the acceptance of 'dominant ideologies/ discourses' is not necessary for the individual to partake in the reproduction of the socio-economic order. Indeed, ideology is much more important in determining its development.

The theory I propose in this book attempts to combine classic Marxist concepts with Antonio Gramsci's notion of hegemony, Bourdieu's habitus/ field dichotomy, and William James' conceptions of interest and belief. This apparently strange combination seems to me necessary insofar as the problem of ideology must be considered both from the individual perspective (since it is about people accepting/rejecting certain views of the social world instead of others), but also from the macro-perspective as it leads to collective action which has broad social consequences. The knowledgeable reader might have a problem with constructing a Marxist theory of this sort. Indeed, general theories (especially Marxist ones) have been deemed impossible insofar as they imply a teleological reading of reality (where everything that will happen can be predicted simply by appeal to the theory's own logics). In other words, Marxist theories have been criticised for 'answering questions' without the need of empirical analysis. This is a legitimate criticism against some versions of historical materialism (e.g., G. A. Cohen's). However, this is something I seek to avoid. What I propose here is not a theory through which one is able to answer historic questions a-priori, without any analysis. But rather, a theoretical framework by means of which one might formulate hypotheses. As S. H. Rigby puts it, historical materialism

is more useful when it is seen as a historical theory which allows us to ask questions and construct hypotheses, rather than as a means of supplying ready-made answer. It is its concepts and questions which distinguish 'Marxist' history from other histories, rather than its forms of research and validation. ${ }^{9}$

This book will propose definitions of Marxist concepts as well as explaining their relationship to one another. I believe that by understanding them together in a systematic manner, they could be helpful when analysing social reality. However, I offer no pre-made formulas to explain events, crises, transformations, etc. Although the concepts presented can be used to construct hypotheses on such matters, the answers must be searched empirically. Furthermore, although I attempt to create a Marxist framework that is based on a close reading of his works, I make absolutely no claim to be offering what the 'true' Marx meant. This would be a ridiculous claim to make, especially considering all the ambiguities within his writings. Overall, I believe that Marxist concepts are superior to those presented by other critical thinkers, and that their systematisation can lead us to a more sophisticated understanding of the social world. Whether I am right is for critics to decide.

9 Rigby, S. H. (1998) p. 300. 


\section{Introduction}

Having introduced our enterprise, we can now provide a brief overview of this work's structure. The reader must bear in mind that this book seeks to answer the following question: What are the roles of ideology within the reproduction and development of the socio-economic order from a Marxist perspective?

In the first chapter, I will present a further justification of this project, which will be carried out by assessing criticisms against Marx's theory as well as the alternatives proposed by various critical thinkers. There will also be a discussion of criticisms directed against any systematisation of Marx's thought and the possibility for a theory of ideology. The final part of this chapter will be dedicated to an assessment of Theodor Adorno's and Slavoj Žižek's notions of ideology. Overall, the chapter will try to prove the everlasting importance of Marx's works, as well as the need for (another) theory of ideology. In Chapter 2 we will delve into the controversy surrounding Marx's historical materialism and ideology. The chapter will begin by introducing nine propositions which are central to this debate. After that, it will briefly address the theories of Lukács and Althusser, to familiarise our reader with some of the problems surrounding Marx's materialism and its relationship to ideology. Then, we will focus on more recent secondary literature, in particular the works of Paul Ricoeur, Jorges Larrain, Terry Eagleton, Michael Rosen and Jan Rehmann. Their works are indeed interesting as they provide a close reading of Marx's texts as well as different interpretations of salient passages. In fact, while Ricoeur, Larrain and Rehmann argue that Marx's method is coherent throughout his writings and that he also presented a coherent theory of ideology, Rosen and Eagleton argue that Marx's method and his theory of ideology are filled with ambiguities and contradictions. My position is somewhere in-between those two interpretations. I will argue that although Marx's materialist method has been coherently stated throughout his writings, and that a general theory of formation of ideas is implied by this framework, his use of the term ideology is too ambiguous and inconsistent. While some hints towards a definition of ideology are implicit in the structure/superstructure dichotomy, the concept is too underdeveloped in Marx for us to create our theory out of his works alone. Because of those lacks, those concepts will be analysed again through Gramsci's Prison Notebooks in Chapter 4.

Chapter 3 will be dedicated to Marx's theory of commodity fetishism. Two reasons make this discussion necessary. First, (as we will see) commodity fetishism is often associated with ideology. It is therefore important for us to clarify what this concept means and whether it is connected with the question of ideology. Second, since Eagleton argues that Marx's theory of fetishism clashes with what he says in the '1859 Preface' to A Contribution to the Critique of Political Economy and in The German Ideology, efforts will be made to demonstrate its compatibility with the rest of his materialist method. The overall aim of this chapter is to prove that Marx's theory of commodity fetishism is a sub-theory of (or an application of) the general theory of 
formation of ideas elaborated in Chapter 2. I will also argue that capitalist relations of production make our consent for the socio-economic order appear spontaneous and voluntary.

Chapter 4 will focus on Gramsci's interpretation of historical materialism through a discussion of his Prison Notebooks. In this chapter I will argue that Gramsci's philosophy of praxis represents a coherent and defensible reading of Marx's materialism. The importance of the concept of practice/praxis will also be further developed. Gramsci's concepts of the relations of forces and the permanentloccasional dichotomy will be employed to interpret Marx's basel superstructure metaphor. His notion of hegemony will also be explained in some depth and understood as a theory of social influence by means of domination and leadership. Overall, this chapter will seek to address the issues our previous reading of Marx left unsolved, as well as providing the reader with a definition of ideology.

Chapter 5 will present a systematisation and synthesis of previously gathered insights, through which my interpretation of historical materialism and ideology will be further developed in combination with the concepts borrowed from Bourdieu and James. This chapter will also discuss hegemonic crises of leadership and ideologies' reliance on past constructs. 


\section{Bibliography}

Abercrombie, N., Turner, B. S., Hill, S. (2015) The Dominant Ideology Thesis. New York: Routledge.

Adlam, D., Henriques, J., Rose, N., Salfield, A., Venn, C. and Walkerdine, V. (1977) Psychology, ideology and the human subject. Ideology and Consciousness, 1(2), pp. $1-56$.

Adorno, T. (2004) Negative Dialectics. London: Routledge.

Allison, D. B. (1979) Translator's Introduction. In: Derrida, J., Speech and Phenomena and Other Essays on Husserl's Theory of Signs. Evanston: NorthWestern University Press.

Althusser, L. P. (2005) For Marx. London: Verso.

Althusser, L. P. (2014) On the Reproduction of Capitalism: Ideology and the Ideological State Apparatuses. London: Verso.

Althusser, L. P. (1998) Reading Capital. London: Verso.

Anderson, P. (1976) The Antinomies of Antonio Gramsci. New Left Review. 100.

Baring, E. (2011) The Young Derrida and French Philosophy, 1945-1968. Cambridge: Cambridge University Press.

Bonefield, W., Gunn, R. and Psychopedis, K. (1992) Open Marxism Vol. 1. London: Pluto Press.

Bourdieu, P. (2000) Pascalian Meditations. Stanford: Stanford University Press.

Brenner, R. (2007) Property and Progress: Where Adam Smith Went Wrong. In: Wickham, C. (ed), Marxist History-writing for the Twenty-first Century. Oxford: Oxford University Press.

Callinicos, A. (1976) Althusser's Marxism. London: Pluto Press.

Castoriadis, C. (1990) An Interview. Radical Philosophy. 56.

Castoriadis, C. (2005) The Imaginary Institution of Society. Malden: Polity Press.

Cohen, G. A. (2000) Karl Marx's Theory of History: A Defence. Oxford: Oxford University Press.

Cox, R. (1996) Approaches to World Order. Cambridge: Cambridge University Press.

Crocker, L. (1980) Marx's Use of Contradiction. Philosophy and Phenomenological Research. 40(4), pp. 558-563.

Derrida, J. (2008) Ghostly Demarcations. London: Verso.

Derrida, J. (2002) Negotiations: Interventions and Interviews, 1971-2001. Stanford: Stanford University Press.

Derrida, J. (1998) Of Grammatology. Baltimore: Johns Hopkins University Press.

Derrida, J. (2006) Specters of Marx. New York: Routledge. 
Derrida, J. (1979) Speech and Phenomena and Other Essays on Husserl's Theory of Signs. Evanston: Northwestern University Press.

Eagleton, T. (1991) Ideology: An Introduction. London: Verso.

Engels, F. (2004) Engels to Franz Mehring. In: Collected Works Vol.50. London: Lawrence and Wishart.

Engels, F. (1989) Karl Marx’s Funeral. In: Collected Works Vol.24. London: Lawrence and Wishart.

Fisher, M. (2012) What is Hauntology? Film Quarterly. 66(1).

Fuchs, C. (2014) Digital Labour and Karl Marx. New York: Routledge.

Geras, N. (1971) Essence and Appearance: Aspects of Fetishism in Marx's Capital. New Left Review. 65.

Gramsci, A. (1973) Lettere Dal Carcere. Turin: Einaudi.

Gramsci, A. (2011) Prison Notebooks, vol.1,2,3. New York: Columbia University Press.

Gramsci, A. (2014) Quaderni del Carcere, vol.1,2,3. Turin: Einaudi.

Gerstenberger, H. (1992) The Bourgeois State Form Revisited. In: Werner, B., Richard, G. and Psychopedis, K. (eds), Open Marxism. vol. 1. London: Pluto Press.

Hall, S. (2005) Critical Dialogues in Cultural Studies. London: Routledge.

Hall, S. (1988) The Toad in the Garden: Thatcherism among the Theorists. In: Nelson, C., Grossberg, L. (eds), Marxism and the Interpretation of Culture. Urbana: University of Illinois.

Holloway, J. (2005) Change the World without Taking Power: The Revolution Today. London: Pluto Press.

Holloway, J. (1995) From Scream of Refusal to Scream of Power: The Centrality of Work. In: Werner, B., Gunn, R., Holloway, J. and Psychopedis, K. (eds), Open Marxism. vol. 3. London: Pluto Press.

Horkheimer, M. (1975) Critical Theory: Selected Essays. New York: Continuum.

Horkheimer, M. (2018) The State of Contemporary Social Philosophy and the Tasks of an Institute for Social Research. Journal for Cultural Research. 22(2).

Horkheimer, M. and Adorno, T. (2002) Dialectic of Enlightenment: Philosophical Fragments. Stanford: Stanford University Press.

James, W. (1916) Talks to Teachers on Psychology; and to Students on Some of Life's Ideals. New York: Henry Hold and Company.

James, W. (1983) The Principles of Psychology. Cambridge: Harvard University Press.

Jameson, F. (2008) Marx's Purloined Letter. In: Sprinker, M. (ed), Ghostly Demarcations: A Symposium on Jacques Derrida's Specters of Marx. London: Verso.

Jay, M. (1972) The Frankfurt School's Critique of Marxism. Social Research. 39(2).

Klooger, J. and Howard, D. (2009) Castoriadis: Psyche, Society, Autonomy. Leiden: Brill.

Laclau, E. and Mouffe, C. (2001) Hegemony and Socialist Strategy: Towards a Radical Democratic Politics. London: Verso.

Larrain, J. (1983) Marxism and Ideology. London: Macmillan.

Larrain, J. (1979) The Concept of Ideology. London: Hutchinson University Library.

Lewis, T. (2008) The Politics of 'Hauntology' in Derrida's Specters of Marx. In: Sprinker, M. (ed), Ghostly Demarcations: A Symposium on Jacques Derrida's Specters of Marx. London: Verso.

Liguori, G. (2015) Gramsci's Pathways. Leiden: Brill.

Lukács, G. (1971) History and Class Consciousness: Studies in Marxist Dialectics. Cambridge, MA: MIT.

Lukács, G. (1978) The Ontology of Social Being Vol.2: Marx. London: Merlin Press. 
Markus, G. (1987) Ideology, Critique and Contradiction in Marx: Answering J. Larrain. Canadian Journal of Political and Social Theory. 11(3).

Marx, K. (1992a) A Contribution to the Critique of Hegel's Philosophy of Right. In: Early Writings. Harmondsworth: Penguin in Association with New Left Review.

Marx, K. (1990) Capital: A Critique of Political Economy Volume I. London: Penguin Books in association with New Left Review.

Marx, K. (1992b) Critique of Hegel's Doctrine of the State. In: Colletti, L. (ed), Early Writings. Harmondsworth: Penguin in Association with New Left Review.

Marx, K. (1992c) Economic and Philosophical Manuscripts of 1844. In: Colletti, L. (ed), Early Writings. Harmondsworth: Penguin in Association with New Left Review.

Marx, K. and Engels, F. (1987b) 1859 Preface to A Contribution to the Critique of Political Economy. In: Collected Works Vol.29. London: Lawrence and Wishart.

Marx, K. and Engels, F. (1998) Capital Volume III. In: Collected Works Vol.37. London: Lawrence and Wishart.

Marx, K. and Engels, F. (1988) Economic Manuscript of 1861-63. In: Collected Works Vol.30. London: Lawrence and Wishart.

Marx, K. and Engels, F. (1987a) Grundrisse. In: Collected Works Vol.28. London: Lawrence and Wishart.

Marx, K. and Engels, F. (2001) Letter from Engels to Joseph Bloch. In: Collected Works Vol.49. London: Lawrence and Wishart.

Marx, K. and Engels, F. (1976a) Manifesto of the Communist Party. In: Collected Works Vol.6. London: Lawrence and Wishart.

Marx, K. and Engels, F. (1979) The Eighteenth Brumaire of Louis Bonaparte. In: Collected Works Vol.11. London: Lawrence and Wishart.

Marx, K. and Engels, F. (1976b) The German Ideology. In: Collected Works Vol.5. London: Lawrence and Wishart.

Marx, K. and Engels, F. (1980) The Question of the Abolition of Serfdom in Russia. In: Collected Works Vol.16. London: Lawrence and Wishart.

Marx, K. and Engels, F. (1989) Theories of Surplus Value. In: Collected Works Vol.32. London: Lawrence and Wishart.

Marx, K. and Engels, F. (1976c) Theses on Feuerbach. In: Collected Works Vol.5. London: Lawrence and Wishart.

McCarney, J. (1980) The Real World of Ideology. Brighton: Harvester Press.

McDonough, R. (1978) Ideology as False Consciousness: Lukács. In: Centre for Contemporary Cultural Studies, On Ideology. London: Hutchinson.

Memos, C. (2014) Castoriadis and Critical Theory. Basingstoke: Palgrave.

Negri, A. (1992) Interpretation of the Class Situation Today: Methodological Aspects. In: Werner, B., Richard, G. and Psychopedis, K. (eds), Open Marxism Vol. 2. London: Pluto Press.

Negri, A. (1991) Marx Beyond Marx: Lessons on the Grundrisse. London: Pluto Press. Negri, A. and Hardt, M. (2000) Empire. Cambridge: Harvard University Press.

Negri, A. and Hardt, M. (2004) Multitude: War and Democracy in the Age of Empire. New York: The Penguin Press.

Orwell, G. (2013) Nineteen Eighty-Four. London: Penguin Books.

Pilling, G. (2010) Marx's 'Capital' (Routledge Revivals): Philosophy and Political Economy. New York: Routledge.

Postone, M. (1998) Review: Deconstruction as Social Critique: Derrida on Marx and the New World Order. History and Theory. 37(3). 
Rehmann, J. (2013) Theories of Ideology: The Powers of Alienation and Subjugation. Leiden/Boston: Brill.

Resnick, S. and Wolff, R. (1989) Knowledge and Class: A Marxian Critique of Political Economy. Chicago: University of Chicago Press.

Ricoeur, P. (1986) Lectures on Ideology and Utopia. New York: Columbia University Press.

Rigby, S. H. (1998) Marxism and History: A Critical Introduction. Manchester: Manchester University Press.

Rosen, M. (1996) On Voluntary Servitude: False Consciousness and the Theory of Ideology. Cambridge: Polity Press.

Rubin, I. I. (1990) Essays on Marx's Theory of Value. Montreal: Black Rose Books.

Spinoza, B. (2007) A Theologico-Political Treatise, and a Political Treatise. New York: Cosimo Classics.

Stimolo, M. (2015) On Derrida's Critique of the Metaphysics of Presence. Implications for Scientific Inquiry. In: The Concept of Time in Early Twentieth-Century Philosophy. Springer. Available at: https://link.springer.com/book/10.1007\%2F978-3-319-24895-0

Therborn, G. (1980) Ideology of Power and the Power of Ideology. London: Verso.

Thomas, P. D. (2009) The Gramscian Moment: Philosophy, Hegemony and Marxism. Leiden/Boston: Brill.

Vattimo, G. and Zabala, S. (2014) Hermeneutic Communism. New York: Columbia University Press.

Williams, R. (1977) Marxism and Literature. Oxford: Oxford University Press.

Wood, E. M. (2003) Democracy against Capitalism: Renewing Historical Materialism. Cambridge: Cambridge University Press.

Žižek, S. (2014) Absolute Recoil: Towards a New Foundation of Dialectical Materialism. London: Verso.

Žižek, S. (2009) First as Tragedy then as Farce. London: Verso.

Žižek, S. (2012) Less than Nothing: Hegel and the Shadow of Dialectical Materialism. London: Verso.

Žižek, S. (2012) Mapping Ideology. London: Verso.

Žižek, S. (2006) The Parallax View. Cambridge: MIT Press.

Žižek, S. (2008) The Sublime Object of Ideology. London: Verso. 